удк

\title{
МОДЕЛИРОВАНИЕ ТРАНСФОРМАТОРА С СЕМЬЮ ВЫВОДАМИ ДЛЯ МАЛОБЮДЖЕТНОГО КВАДРАТУРНОГО ГЕНЕРАТОРА СО СВЯЗАННЫМИ ЗАТВОРАМИ*
}

\author{
МИНЛИН МА ${ }^{1,2}$, ЮАН ЧЕН ${ }^{1}$, СЯНЛЯН ДЖИН ${ }^{1,2}$, ДЖИДЖУН ЛИ ${ }^{1}$, ЧЕНВЕЙ ЛИ ${ }^{1}$, СЮЭ ЧЖАН $^{1}$ \\ ${ }^{1}$ Сянтаньский университет, \\ Китай, Сянтань, 411105, Хунань \\ ${ }^{2}$ Хунаньская техническая лаборатория микроэлектроники, оптоэлектроники и систем на кристалле, \\ Китай, Сянтань, Хунань
}

\begin{abstract}
Аннотация. В статье представлены результаты разработки трансформатора с семью выводами. Предложена его эквивалентная схема. Трансформатор содержит первичную обмотку с отводом средней точки и две вторичные обмотки. На основе этого трансформатора разработан малобюджетный квадратурный генератор со связанными затворами с использованием 0,18 мкм КМОП технологии. При напряжении питания 1 В квадратурный генератор потребляет мощность 7 мВт. Полученный уровень фазовых шумов при отстройке от несущей частоты на 1 МГц составил $-116,3$ дБ/Гц. Площадь, занимаемая генератором на кристалле, равна $400 \times 500$ мкм.
\end{abstract}

Ключевые слова: малобюджетное устройство; устройства на основе трансформаторов; генератор; квадратурный генератор

\section{1. ВВЕДЕНИЕ}

Стремительное развитие беспроводных технологий приводит к росту потребности в малобюджетных, маломощных интегрированных радиочастотных приемопередатчиках с низким уровнем фазовых шумов [1-3]. Известно, что квадратурные генераторы теоретически могут удовлетворять всем этим техническим требованиям.

Существуют следующие схемы и методы генерации квадратурных сигналов: полифазные $R C-C R$ фильтры, кольцевые генераторы, частотные делители и частотно-связанные устройства. Наиболее часто используются топологии частотных делителей и частотно-связанных устройств.

Квадратурные генераторы с делителем на два работают на двойной частоте [4]. Недостатком квадратурных генераторов на основе трансформаторов является их более высокая потребляемая мощность и более высокий уровень фазовых шумов или повышенное напряжение питания $[1,3]$.

* $\quad$ Работа финансово поддержана Государственной программой Китая по финансированию естественных наук (Грант № 61233010), Фондом поддержки естественных наук Китая (№ 61176032), программой финансирования администрации образования провинции Хунань (№ 14С1072) и проектом по естественным наукам провинции Хунань (№ 2015JJ2140). 